\title{
まちなか回遊行動の詳細分析と 政策シミュレーションのための予測モデル
}

\author{
荒木 雅弘 $1 \cdot$ 溝上 章志 $2 \cdot$ 円山 玩也 ${ }^{3}$ \\ 1学生会員 名古屋大学大学院工学研究科（干464-8603 名古屋市千種区不老町） \\ E-mail: araki.masahiro@j.mbox.nagoya-u.ac.jp \\ 2正会員 熊本大学教授 大学院自然科学研究科（干860-8555 熊本市中央区黒髪2-39-1） \\ E-mail: smizo@gpo.kumammoto-u.ac.jp \\ 3正会員 熊本大学准教授 政策創造研究教育センター（テ860-8555 熊本市中央区黒髮2-39-1） \\ E-mail: takumaru@kumammoto-u.ac.jp
}

\begin{abstract}
近年，熊本市では，中心市街地の魅力と活力向上のために様々な施策がとられている．その中でも， 人々の回遊行動を促進させることは, 中心市街地を活性化させる有効な施策のひとつであると考えられて いる. そのためには, 歩行者の回遊行動の実態を詳細に分析し, 回遊行動に影響を及ぼす要因とメカニズ ムを明らかにすることが必要である. 本研究では, 街路構成指標なども説明変数として導入して, まちな かの空間的魅力向上のための政策提言に活用できるモデルを構築する。その後, 現在熊本市が計画してい る桜町地区の再開発事業「桜町地区第一種市街地再開発事業」が来街者の回遊行動に与える効果を政策シ ミュレーションによって分析することを目的としている.
\end{abstract}

Key Words : excursion behavior, nested logit model, survival analysis, city center, space syntax theory

\section{1. はじめに}

九州新幹線鹿児島ルートの全線開通や政令市一の移 行などにより, 近年, 熊本市を取り巻く環境は大きく 変化し, 政令指定都市としてさらなる飛躍が期待され ている，一方で，居住者や商業機能の郊外移転による 中心商店街での歩行者交通量や小売販売額の減少, 低・未利用地の増加など, 中心市街地の活力の低下が 懸念されている.

これらの課題を解決する為に, 熊本市は熊本市中心 市街地活性化基本計画の策定や花畑・桜町地区の再開 発事業の計画を進めており, 中心市街地の魅力創造と 活力向上に力を入れている.これらの施策のなかでも, 来街者の回遊を促進することは中心市街地を活性化さ せる有効な施策の一つと考えられる，そのためには， 歩行者の回遊行動の実態を詳細に分析し, 回遊行動に 影響を及ぼす要因とそのメカニズムを明らかにするこ とが必要である.

本研究では, 市街地の空間・街路網構成などを表す 評価指標を説明変数に導入し，まちなかの空間的魅力 向上のための政策の提言に利用できるような回遊行動 の調査方法とその記述モデルを提案する. その後, 現
在，熊本市が都市計画決定した桜町地区の再開発事業 「桜町地区第一種市街地再開発事業」が来街者の回遊 行動に与える影響を, 回遊行動モデルを組み込んだ政 策シミュレーションを用いて予測することを目的とす る. 本研究の対象エリアは, 図-1に示寸熊本市中心市 街地活性化基本計画の対象エリアである通町・桜町地 区である.

本研究は全6章で構成される.2章では回遊行動を記

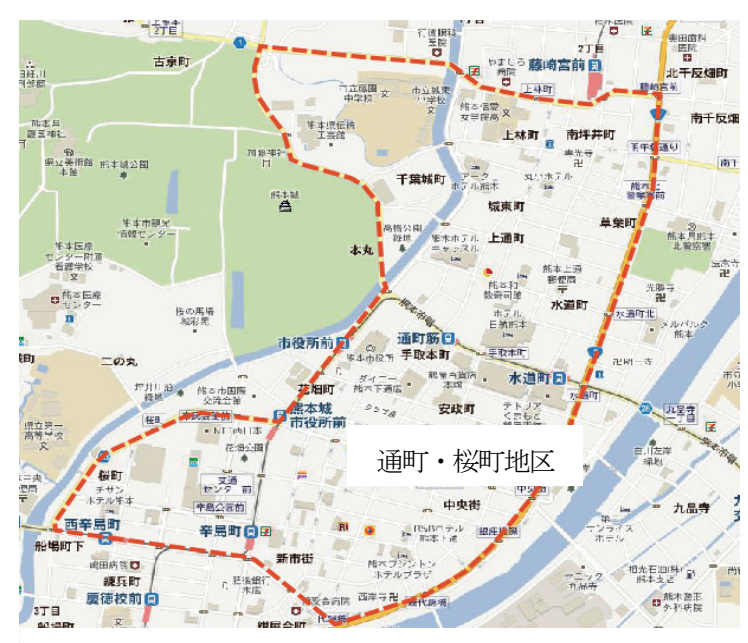

図-1 分析対象エリア 
述する目的地選択モデルと滞在時間モデルからなる時 空間回遊行動モデルの構造と定式化，およびモデルの 推定のためのデータとして用いる熊本中心市街地にお ける歩行者回遊行動アンケート調査とゲートカウント 調査について説明する. 目的地選択は地区の界隈性や 入り込みやすさのような街路網構成にも依存寸る．3章 では, 中心市街地の街路網構成の評価指標として導入 したスペースシンタックス理論によるインテグレーシ ヨン值（Int 值）の概念と算出方法について解説し，回 遊行動モデルへの導入方法について説明する．4章では それぞれのモデルの推定結果を述べ，その考察を行う. 5章では構築した回遊行動モデルの現況再現の検証，お よび桜町地区第一種市街地再開発事業への政策シミュ レーションの結果を考察する. 最後に本研究の成果と 今後の課題について6章でまとめる.

\section{2. 回遊行動調査と回遊行動モデル}

\section{(1) 既存研究の課題}

来街者の回遊行動と中心市街地の空間構成との関係

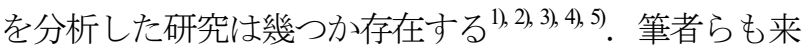
街者の中心市街地での回遊ルートと訪問先での滞在時 間を予測する時空間回遊行動モデルのプロトタイプを 提案し，休日に行った熊本中心市街地回遊行動アンケ 一ト調査データを用いたモデルの推定を行ってきた. しかし，いずれも，回遊行動モデルに導入された説明 変数が店舗への移動時間や店舗面積などの標準的な変 数であり, 街路網構成によって創出される訪問先店舗 が存在する街区全体のもつ雾囲気などの特性が考慮さ れていない，また，適合度があまり良くないなどの課 題があった。より詳細に来街者の回遊行動を表現する ためには，現訪問店舗からの移動時間や目的地店舗の 店舗面積などの直接的要因だけではなく, 店舗への空 間的なアクセスのしやすさや店舗の存在する地区全体 が持つ空間的魅力などを考慮するなど，多様でより詳 細な要因を導入する必要がある.さらに，上述の回遊 行動モデルは休日サンプルを用いたモデルの推定を行 っているため, 平日サンプルを用いたモデルの推定も 行い，平日と休日の比較分析を行い，その違いを明ら かにすることもことも有用であろう. 本研究では, 店 舗選択モデルに街路構成指標などを説明変数に追加的 に導入し，平日および休日のサンプルによるモデル推 定を行って，来街者のまちなかにおける回遊行動を詳 細に分析することを目的とする.

\section{(2) 回遊行動モデルの概要}

本研究では, 回遊行動を中心市街地の入口から出発

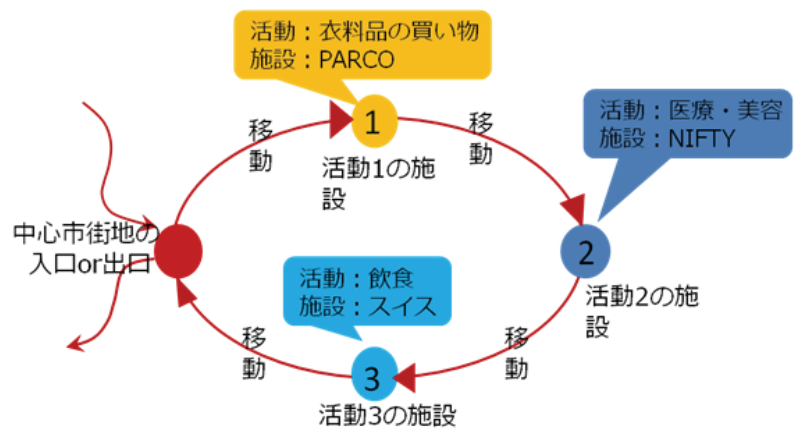

図-2 回遊行動の概念図

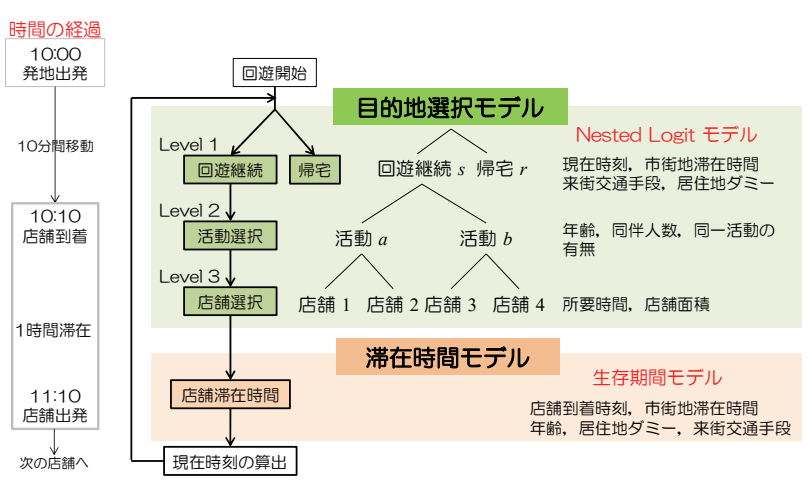

図-3回遊行動モデルの概要

して，時間の経過に沿っていくつかの店舗を訪問した 後に出口から帰宅するといった，時・空間上の一連の 流れと定義する．図-2にその概念図を示す．来街者の 回遊行動を，回遊を継続するか，継続するという条件 下でどの活動を行うか，その活動を行うという条件下 でどの店舗を訪問し，そこで何分間滞在するかという 段階的な離散選択と継続時間選択行動として記述する.

図-3に示寸ように，3レベルのネスティッドロジット モデルによる目的地選択モデルと生存期間モデルによ る店舗滞在時間モデルを組み合わせることによって, 時空間回遊行動をモデル化する. 目的地選択モデルで は，Level-1で回遊継続か帰宅か選択，Level-2で買物や飲 食などの活動内容の選択，Level-3で活動内容を選択し た条件下での各店舗の選択という構造を仮定している.

目的地選択モデルによって店舗が決定すると，その 時点の現在時刻に発地点からその店舗までの所要時間 を加えることで到着時刻を求めることができる，店舗 到着後はその店の魅力度や到着時刻などによって滞在 時間が決定されると仮定する。これら店舗間の移動時 間と店舗滞在時間の総和が市街地滞在時間となる。こ れらに影響をうけてLevel-1における回遊継続か帰宅す るかの選択に戻る。これを帰宅が選択されるまで繰り 返す。

通常，来街者には滞在時間に制約があることから， 時間制約下で効用を最大にする活動や移動の選択を行 
うという概念に基づいた，いわゆる活動時間配分型の モデルの適用も有効かもしれない. しかし，本モデル では時間制約については明示的に考慮せず，回遊継続 か州宅かの選択肢の効用を現時刻や市街地滞在時間の 関数とすることによって，間接的に時間制約を考慮し ている.この考え方は, トリップチェーンや広域観光 周遊など, 時空間的に連続する活動と移動の選択行動 のモデル化にも活用できる.

\section{a) 目的地選択モデル}

図-3の目的地選択モデルに示した簡易的なネスティ ッドロジットモデルの選択ツリーにおいて, 店舗 $i$ を選 択する確率 $P_{i}$ は次で表される.

$$
P_{i}=P(s) \cdot P(a \mid s) \cdot P(i \mid a)
$$

ここで， $P(s)$ は回遊継続を選択する確率， $P(a \mid s)$ は回遊継続を選択したという条件下で活動 $a$ を選ぶ条件 付き確率, $P(i \mid a)$ は活動 $a$ を選んだという条件下で占 舗 $i$ を選択する条件付き確率であり，それぞれ以下のよ うに表される。

$$
\begin{gathered}
P(s)=\frac{\exp \left\{\lambda_{2}\left(V_{s}+I_{s}\right)\right\}}{\exp \left\{\lambda_{2}\left(V_{s}+I_{s}\right)\right\}+\exp \left\{\lambda_{2}\left(V_{r}+I_{r}\right)\right\}} \\
P(a \mid s)=\frac{\exp \left\{\lambda_{1}\left(V_{(a \mid s)}+I_{a}\right)\right\}}{\exp \left\{\lambda_{1}\left(V_{(a \mid s)}+I_{a}\right)\right\}+\exp \left\{\lambda_{1}\left(V_{(b \mid s)}+I_{b}\right)\right\}} \\
P(i \mid a)=\frac{\exp \left(V_{(i \mid a)}\right)}{\sum_{i \in j_{a}} \exp \left(V_{(i \mid a)}\right)}
\end{gathered}
$$

ここで， $I_{a}, I_{b}, I_{s}, I_{r}$ は以下で定義される合成変 数である.

$$
\begin{aligned}
& I_{a}=\frac{1}{\lambda_{1}} \ln \left\{\sum_{i \in j_{a}} \exp \left(\lambda_{1} V_{(i \mid a)}\right)\right\} \\
& I_{b}=\frac{1}{\lambda_{1}} \ln \left\{\sum_{i \in j_{b}} \exp \left(\lambda_{1} V_{(i \mid b)}\right)\right\} \\
& I_{s}=\frac{1}{\lambda_{2}} \ln \left\{\sum_{k \in K_{s}} \exp \left(\lambda_{2} V_{(k \mid s)}\right)\right\} \\
& I_{r}=0
\end{aligned}
$$

なお， $J_{a} ， J_{b}$ はそれぞれ活動 $a, b$ が可能な店舗の集 合， $K_{s}$ は活動の集合を示す.

$V$ はそれぞれ個人 $n$ がその選択肢を選択した際の効 用で， $V_{s}$ は回遊継続の固有の効用， $V_{r}$ は帰宅の固有 の効用， $V_{(a \mid s)}, V_{(b \mid s)}$ はそれぞれ活動 $a, b$ を選択した際 の固有の効用である. $V_{(i \mid a)}, V_{(i b)}$ は活動 $a, b$ を選択し たという条件下での店舗 $i$ の効用である.

効用 $V$ には，年齢や性別，回遊したときの人数など の回遊者の属性，訪問店舗の面積や次の目的地までの 所要時間, 複合商業施設かどうかなどの従来から用い ている変数に加えて, 後述する街路構成指標などを新
たに説明変数として導入し，適合度の向上を目指す．

\section{b) 滞在時間モデル}

各店舗における滞在時間を求めるために，生存関数 にワイブル分布を仮定した生存時間モデルを適用する。 生存関数とは, 生存状態から時間 $t$ が経過した後に死亡 状態へ移行している確率を表わす関数であるが，生存 状態を訪問した店舗に滞在している状態，死亡状態を 訪問した店舗を離れる状態とみなす。これによって, その店舗に訪問した時刻から時間 $t$ の経過と共に減少寸 る滞在者の生存確率を表現できる。一般的に生存関数 には指数分布を用いるが，本研究では分布の形状を決 定する形状パラメータを任意に考慮することができ， 滞在時間を詳細に表現できるワイブル分布を仮定して いる.

時点 $t$ において個人 $n$ が店舗にいる確率 $S(t)$ として, その確率分布関数が

$$
S(t)=\exp \left\{-(\beta t)^{\alpha}\right\}
$$

のワイブル分布を仮定すると, 時点 $t$ において個体 $n$ が 店舗から離れている確率 $F(t)$ は次式で表わされる.

$$
F(t)=1-\exp \left\{-(\beta t)^{\alpha}\right\}
$$

また，その確率密度関数は次式で表わされる。

$$
f(t)=\frac{d f(t)}{d t}=\alpha \beta t^{\alpha-1} \cdot \exp \left\{-(\beta t)^{\alpha}\right\}
$$

ここで，パラメータ $\alpha は$ 時間的スケールに対応した尺 度パラメータであり， $\alpha>1$ のとき, 八ザード関数は $t$ の単調増加関数であり, $\alpha<1$ のとき, $t$ の単調減少関 数となる. 一方, パラメータ $\beta$ は分布の形状を決める形 状パラメータであり，この值が大きいほど早い時間に 急激に店舗から離れる確率が高くなることを示寸．本 研究では, 上記のパラメータ $\beta$ を

$$
\beta=\exp \left(b_{0}+b_{1} y_{1}+b_{2} y_{2}+\cdots+b_{m} y_{m}\right)
$$

のように定式化した．ここで， $y_{i}(i=1, \cdots, m)$ は現在 時刻や個人属性などの説明変数である.

\section{（3）中心市街地における回遊行動調査の概要}

本研究では，2011年に実施した熊本中心市街地にお ける商店街通行量調查, ゲートカウント調查, 歩行者 回遊行動アンケート調査のデータを使用する. 以下に それぞれの調查の概要を述べ, 調査項目などの詳細を 表-1〜表-3に示す.

\section{a) 商店街通行量調査}

商店街通行量調査は, 熊本市と熊本商工会議所によ つて例年8月の日曜と平日にそれぞれ1回ずつ実施され ている歩行者の断面通行量調査のである. 中心市街地26 地点を含む市内36地点で行われているが，新たに導入 
したゲートカウント調査との重複のため，2011年には 主要5地点でのみ行われている.

\section{b) ゲートカウント調査}

前述の商店街通行量調查は中心市街地の26の断面だ けでの調査のため, 市街地全体の空間的な歩行者の分 布は捉えることが出来ない. ゲートカウント調査は, 調查員が5分ごとに調查地点を移動しつつ，その間の通 行量を記録する調查である，そのため299地点という多 くの地点における通行量データを得ることができ, 歩 行者の空間的な分布を把握することが可能である.

\section{c) 歩行者回遊行動アンケート調査}

この調查は，熊本市中心市街地に訪問する人がどの ような目的で来街し, ぞのようなルートで回遊し, 活 動を行っているかを把握するために実施された。 バス 停や電停, 駐車場や駐輪場, バス停や電停, 駐車場や 駐輪場などの回遊の入出地点において, 来街者が中心 市街地から帰宅する際に，その日1日の回遊行動をヒア リングする方法で実施した，そこでは，被験者の個人 属性や来街目的のほかに, 回遊開始地点から終了地点 間の実際に通った回遊ルート，訪問した店舗・施設名， および，そこでの活動（買物，飲食，娛楽，観光など） と滞在時間，購入品目，消費金額などを質問している. このアンケート調查はサンプル調査であるため, 何 らかの方法でサンプルを拡大する必要がある. 拡大の 具体的な方法については5章で後述する.

\section{3. 街路構成の回遊行動モデルへの導入}

本研究では，まちなかにおける人の回遊行動を誘引 する要因として, 著者らのプロトタイプモデルに導入 されていた店舗間の移動時間や訪問先店舗の魅力度に 加えて, 空間的なアクセスのしやすさやその区域の界 隈性を表す街路構成指標として，スペースシンタック ス（SS）理論によるインテグレーション值（Int 值） 7, 8) を用いる. Int 值は，心理学における人の空間認知を考 えた際の「見えること（視認可能）」や「真つ直ぐた どり着けること（直線的に移動可能）」による影響度 を指標化したものであり，それによって人が通りやす い空間かどうかの評価や街路網構成の評価, 犯罪の発 生リスク分析などにも活用されている.

Int 值は位相幾何学的に空間相互の「繋がり方」を分 析寸ることで他の空間からのアクセスのしやすさを指 標化できる. 空間の「繋がり方」の捉え方によって, 認知モデルと動線モデルという 2 種類の分析が可能で ある，前者は，直線的に認知可能な最長の軸線（Axial
表-1 商店街通行量調査の概要

\begin{tabular}{c|l}
\hline 調査日 & 2011 年 8月 19日(金), 21 日(日) \\
\hline 調査時間 & $8: 00-20: 00$ の 12 時間 \\
\hline 調査地点 & 熊本市中心市街地における 5 地点 \\
\hline 調査対象 & 歩行者及び目転車通行者 \\
\hline
\end{tabular}

表-2 ゲートカウント調查の概要

\begin{tabular}{|c|c|}
\hline 調査日 & $\begin{array}{l}\text { 2011年 } 10 \text { 月 } 21 \text { 日(金) } \\
2011 \text { 年 } 11 \text { 月 } 13 \text { 日(日) }\end{array}$ \\
\hline 調査時間 & $\begin{array}{lc}8: 30 \sim 9: 30 & 9: 30 \sim 10: 30 \\
10: 30 \sim 11: 30 & 12: 00 \sim 13: 00 \\
14: 00 \sim 15: 00 & 15: 00 \sim 16: 00 \\
16: 30 \sim 17: 30 & 18: 00 \text { 19:00 } \\
\text { 19:00 20:00 } & \\
\text { 上記のうちのそれぞれある 5 分間 } \\
\end{array}$ \\
\hline 調査地点 & 熊本中心市街地における 299 地点 \\
\hline 調査対象 & 歩行者および自転車通行者 \\
\hline
\end{tabular}

表-3 歩行者回遊行動アンケート調査の概要

\begin{tabular}{|c|c|}
\hline 調査日 & $\begin{array}{l}\text { 2011年 } 10 \text { 月 } 23 \text { 日(金) } \\
2011 \text { 年 } 11 \text { 月 } 13 \text { 日(日) }\end{array}$ \\
\hline 調査時間 & $\begin{array}{ll}1: 12: 00 \sim 13: 00 & 2: 14: 00 \sim 15: 00 \\
3: 16: 00 \sim 17: 00 & 4: 18: 00 \sim 1900\end{array}$ \\
\hline 調査地点 & $\begin{array}{l}\text { 中心市街地・熊本城周辺の主要出口 } \\
\text { 26箇所 }\end{array}$ \\
\hline 調査項目 & $\begin{array}{l}\text { 1: 個人属性(性別・年齢・居住地等) } \\
\text { 2: 来街目的 } \\
\text { 3. 来街手段 } \\
\text { 4: 訪問先(活動・消費行動等) } \\
\text { 5: 回遊ルート }\end{array}$ \\
\hline 得られたサンプル & 平日 561 サンプル 休日 603 サンプル \\
\hline
\end{tabular}

Line）を 1 つの空間とすることから，認識としての空間 の関係性を数值化する. 一方，動線モデルは，直線で 移動可能な軸線を 1 つの空間とするもので, 横断歩道 や歩道の位置や形状，さらには障害物の有無などの情 報をも考慮して線形化するため，実態としての歩行空 間の関係性を数值化できる. これらの值の算出方法に ついては文献 9)を参照されたい.

図-4に熊本市中心市街地の街路網を対象に算出した 動線モデルによる Int 值を示す.一般的に Int 值が高い 街路や空間ほど行きやすく，人の往来が多いアーケー ド商店街や国道では Int 值が高い.しかし，Int值の高い 上通りからの脇道や上乃裏通りなど, Int 值が急に小さ くなる街路で構成される空間にも時間帯によっては回 遊が多く見られる区域が存在する．したがって，訪問 店舗までの経路上の Int 值の変化率や Int 值の地域全体 の平均值なども人の回遊に影響を与えていると考えら れる. 本研究では, 実際の回遊行動に即した形で回遊 行動モデルへの Int 值の導入を図るために, 動線モデル による Int 值を街路構成指標に用いる. 
表-4 中心市街地における活動別の訪問店舗数

\begin{tabular}{l|c|c}
\hline \multirow{2}{*}{ 活動内容 } & \multicolumn{2}{|c}{ 訪問店舗数 } \\
\cline { 2 - 3 } & 平日(\%) & 休日(\%) \\
\hline 1.買物 & $77(43.7)$ & $60(51.7)$ \\
\hline 2.飲食交友 & $45(25.6)$ & $43(37.1)$ \\
\hline 3.咟楽鑑賞 & $13(7.4)$ & $18(15.5)$ \\
\hline 4.用事 & $34(19.3)$ & $12(10.3)$ \\
\hline 5.美容 & $11(6.2)$ & $8(6.9)$ \\
\hline 6.学習 & $21(19.3)$ & $4(3.4)$ \\
\hline 7.観光 & $3(1.7)$ & $2(1.9)$ \\
\hline \multicolumn{1}{|c}{ 計 } & $176(100)$ & $116(100)$ \\
\hline サンプル数 & 325 & 374 \\
\hline \multicolumn{2}{|c|}{}
\end{tabular}

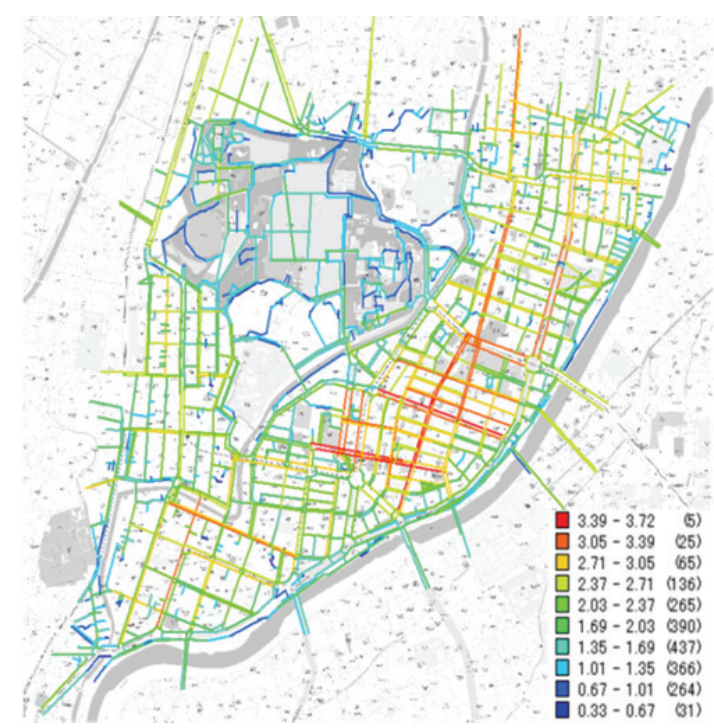

図-4＼cjkstart動線モデルによるInt值の分布

\section{4. 回遊行動モデルの推定}

\section{（1）使用データ}

本研究では，モデルの推定のためのデータとして 2011 年に実施した熊本中心市街地における歩行者回遊 行動アンケート調査データを使用した。回遊行動を行 ったサンプルのうち，モデル推定の際の説明変数とな る個人属性や回遊開始時刻，発ゾーンや訪問先などが 未記入もしくは不明なサンプルは削除している．最終 的にモデル推定に使用できたサンプル人数は平日サン プルが 325 人分 $(642$ トリップ)，休日サンプルが 374 人分 $(574$ トリップ) となっている.

目的地選択モデルの訪問先店舗選択肢は，歩行者回 遊行動アンケート調査に書かれている回遊経路上で一 度でも訪問があった店舗の全てであり，平日が176店舗， 休日が116店舗である，それらを実際にその店舗で行っ た活動別に分類したところ，表-4で示すような数の店 舗選択肢となった，表-4より，1回の回遊についての平 均トリップは, 平日が 1.97 , 休日が 1.53 , 平均訪問店舗

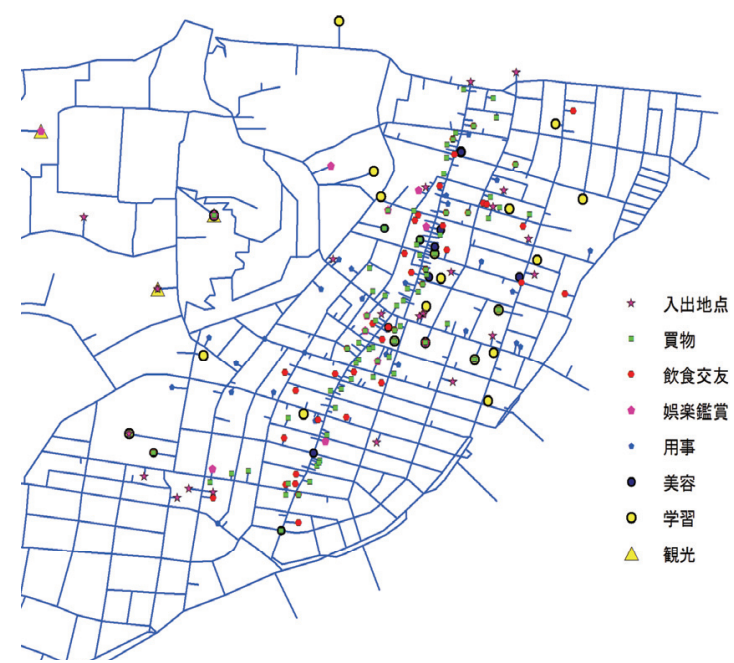

図-5 中心市街地の街路網ネットワークモデル

数は平日が 0.54 , 休日が 0.31 店舗でいずれも平日の方が 多いことが分かる．すべての選択肢店舗数に占める活 動別の店舗選択肢数の比率は，買物と飲食交友，娛楽 鑑賞活動で平日より休日の方がかなり高く，用事と学 習活動では逆に平日の比率がかなり高いなど，平日と 休日では選択肢の構成に違いが見られる.

\section{(2) モデル推定のためのデータ整備 a) 店舗間移動時間}

Level-3の訪問店舗選択モデルでは店舗間の移動時間 が必要になる。ここでは, 中心市街地の街路網をネッ トワークとしてモデル化し，このネットワーク上に全 ての回遊行動サンプルの入出地点（26箇所）と選択肢 となる全ての店舗（267箇所）から成るセントロイドを 設定し，これらのセントロイド間の最短経路探索を行 うことによってセントロイド間移動時間マトリックス を準備した。このネットワークを図-5に示す.

\section{b) 店舗面積}

Level-3の訪問店舗選択モデルでは店舗の魅力度指標 として店舗面積を用いる．選択肢となるすべての店舗 の店舗面積はGISによって店舗の床面積を算出した。な お，2階以上の店舗については1階部分の床面積を用い た.また，ひとつの建物に複数の店舗が入居している 複合商業施設についても，ひとつの店舗とみなし，1階 部分の床面積を用いる.

\section{c) Int 值}

Level-3の訪問店舗選択モデルでは，訪問店舗が存在 する区域の空間的界隈性や訪問先店舗までの街路構成 による行きやすさなどの指標が必要になる．前者につ いては，3章で示した各区域を構成している全てのAxil LineのInt值の平均值および分散を用いる，後者について は，次に訪問する店舗までの目的地までの最短経路上 


\begin{tabular}{|c|c|c|c|c|}
\hline 地区名 & 地区 & 主な通り, 建物 & $I n t$ 平均值 & Int 分散值 \\
\hline \multirow{4}{*}{ 上通北 } & 1-(1) & 上林町 & 1.84 & 0.179 \\
\hline & 1-(2) & 並木坂 & 2.69 & 0.126 \\
\hline & 1-(3) & 上之裏通り北 & 2.48 & 0.184 \\
\hline & 1-(4) & 3 号線北 & 2.27 & 0.252 \\
\hline \multirow{4}{*}{ 上通南 } & 2-(1) & オークス通り & 2.14 & 0.168 \\
\hline & 2-(2) & 上通り & 2.85 & 0.0887 \\
\hline & 2-(3) & 上之裏通り北 & 2.31 & 0.113 \\
\hline & 2-(4) & 3号線中 & 2.34 & 0.278 \\
\hline \multirow{3}{*}{ 下通北 } & 3-(1) & 市役所 & 2.44 & 0.131 \\
\hline & 3-(2) & 下通り銀座北 & 2.61 & 0.185 \\
\hline & 3-(3) & 駕町〜3号線 & 2.48 & 0.281 \\
\hline \multirow{3}{*}{ 下通南 } & 4-(1) & 西銀座, 栄通り & 2.86 & 0.0628 \\
\hline & 4-(2) & 下通り〜新市街 & 3.03 & 0.156 \\
\hline & 4-(3) & シャワー通り, 3号線南 & 2.38 & 0.319 \\
\hline 桜町 & 5 & 交通センター & 2.16 & 0.314 \\
\hline 熊本城 & 6 & 熊本城 & 1.34 & 0.101 \\
\hline
\end{tabular}

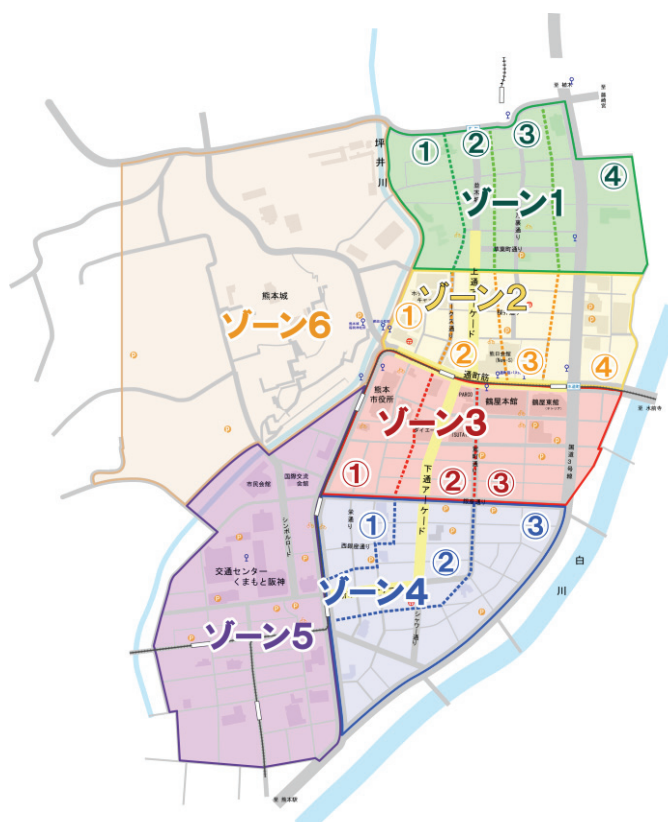

図-6 各ゾーンの Int值の平均と分散

表-5 Level-3 訪問店舗選択モデルの推定結果

\begin{tabular}{c|c|c|c|c}
\hline \multirow{2}{*}{ 説明変数 } & \multicolumn{2}{|c|}{ 平日 } & \multicolumn{2}{c}{ 休日 } \\
\cline { 2 - 5 } & 推定值 & t值 & 推定値 & $\mathrm{t}$ 值 \\
\hline 最短経路の所要時間(h) & -7.91 & -9.02 & -3.08 & -3.49 \\
店舗面積 $\left(1000 \mathrm{~m}^{2}\right)$ & 0.0542 & 3.87 & 0.0368 & 2.87 \\
複合商業施設ダミー(複合商業施設=1) & 5.18 & 15.1 & 3.68 & 18.6 \\
目的地のある地区のInt 平均值 & -0.447 & -2.78 & 0.235 & 1.17 \\
目的地のある地区のInt值の分散 & 1.05 & 1.61 & 3.37 & 4.73 \\
目的地までの最短経路上リンク Int 值の分散 & -0.764 & -2.11 & -1.42 & -3.57 \\
\hline 尤度比 & \multicolumn{2}{|c|}{0.589} & \multicolumn{2}{|c}{0.397} \\
\hline サンプル数 & \multicolumn{2}{|c|}{642} & 574 \\
\hline
\end{tabular}

のリンクを構成するAxil LineのInt值の分散などの指標を 準備しておいた。 図-6には，分析対象地域を15のゾーン に分割し，ゾーンごとに，ゾーン内にある全てのAxial LineのInt值の平均値と分散值を計算した結果を示寸.

\section{（3）目的地選択モデルの推定結果}

以下に目的地選択モデルの推定結果をそれぞれの Levelごとに示す．前述した街路構成評価指標であるInt 值は，Level-3の訪問店舗選択において図-6に示したゾー ン平均Int值（参照），ゾーンのInt值の分散，目的地ま での最短経路が持つInt值の分散という3つの指標を説明 変数として導入している. ゾーン平均Int值とは訪問店 舗が存在するゾーン内の全リンクのInt值の平均值であ り，当該ゾーン全体の平均的な行きやすさを表す．ゾ ーンのInt值の分散はゾーン内の全リンクのInt值の分散 であり，当該ゾーンの空間的界隈性を表す．また，目 的地までの最短経路が持つInt值の分散は, 訪問店舗ま
での最短経路上のリンクのInt值の分散であり，経路上 の空間構成の変動の程度を表す。

なお，本研究では，下位のLevel-3から順に上位のモ デルの推定を行い，最終的にLevel-1の推定を行うとい う段階推定法を用いてモデルの推定を行っている.

\section{a) Level-3 訪問店舗選択モデル}

表-5にLevel-3の訪問店舗選択モデルの推定結果を示す. 尤度比は高く，モデルの適合度は高い。また，いずれ の変数のt值も高く, 統計的に有意である. 平日, 休日 ともに, 所要時間の推定值の符号は負, 店舗面積, 複 合商業施設ダミーの推定值の符号は正となっている. したがって, 訪問店舗までの所要時間が短く, さらに 店舗面積が広く，複合商業施設である方が効用が高い ことを示しており，符号条件は論理的と言えよう。

目的地のある地区の平均Int值の符号は平日が負, 休 日が正の值をとっていることから，平日は地区平均Int 值が小さい地区に存在する店舗の方が効用が高く, 休 
表-6 Level-2 活動選択モデルの推定結果

\begin{tabular}{|c|c|c|c|c|c|}
\hline \multirow{2}{*}{\multicolumn{2}{|c|}{ 説明変数 }} & \multicolumn{2}{|c|}{ 平日 } & \multicolumn{2}{|c|}{ 休日 } \\
\hline & & 推定值 & $\mathrm{t}$ 值 & 推定值 & t值 \\
\hline \multirow{7}{*}{ 定数項 } & 買物 & 3.65 & 2.36 & 4.01 & 2.62 \\
\hline & 飲食交友 & -0.573 & -0.515 & -0.567 & -0.586 \\
\hline & 娛楽鑑賞 & -2.37 & -1.73 & - & - \\
\hline & 用事 & -0.969 & -0.864 & -2.73 & -2.45 \\
\hline & 美容 & -3.03 & -2.03 & -2.64 & -2.04 \\
\hline & 学習 & - & - & -2.66 & -1.97 \\
\hline & 観光 & 3.09 & 2.33 & 2.06 & 2.11 \\
\hline \multirow{3}{*}{$\begin{array}{c}\text { 活動人数 } \\
\text { 年齢 }\end{array}$} & 筫物 & -0.71 & -2.81 & -0.713 & -3.65 \\
\hline & 娛楽鑑賞 & - & - & -0.0418 & -1.56 \\
\hline & 学習 & -0.0432 & -1.44 & - & - \\
\hline 同一活動ダミー & 買物 & 0.948 & 1.97 & -0.124 & -0.307 \\
\hline \multicolumn{2}{|l|}{$\lambda_{1}$} & 0.480 & 4.25 & 0.529 & 4.95 \\
\hline \multicolumn{2}{|c|}{ 尤度比 } & \multicolumn{2}{|c|}{0.497} & \multicolumn{2}{|c|}{0.558} \\
\hline \multicolumn{2}{|c|}{ サンプル数 } & \multicolumn{2}{|c|}{642} & \multicolumn{2}{|c|}{574} \\
\hline
\end{tabular}

表-7 Level-1 回遊継続，帰宅選択モデルの推定結果

\begin{tabular}{|c|c|c|c|c|c|}
\hline \multirow{2}{*}{\multicolumn{2}{|c|}{ 説明変数 }} & \multicolumn{2}{|c|}{ 平日 } & \multicolumn{2}{|c|}{ 休日 } \\
\hline & & 推定值 & $\mathrm{t}$ 值 & 推定值 & $\mathrm{t}$ 值 \\
\hline 回遊継続 & $\begin{array}{l}\text { 現在時刻 } \\
\text { 市街地帯在時間(h) } \\
\text { 居住地ダミー(熊本市在住=1) }\end{array}$ & $\begin{array}{l}-5.42 \\
-0.634 \\
-0.199\end{array}$ & $\begin{array}{c}-2.44 \\
-2.58 \\
-0.691\end{array}$ & $\begin{array}{r}-3.71 \\
-1.86 \\
-0.365\end{array}$ & $\begin{array}{r}-1.67 \\
-3.53 \\
-0.864\end{array}$ \\
\hline 帰宅 & $\begin{array}{l}\text { 定数項 } \\
\text { 公共交通ダミー(公共交通機関=1) }\end{array}$ & $\begin{array}{l}-1.04 \\
0.320\end{array}$ & $\begin{array}{c}-0.554 \\
1.12 \\
\end{array}$ & $\begin{array}{l}-3.18 \\
0.240\end{array}$ & $\begin{array}{l}-1.67 \\
0.581\end{array}$ \\
\hline \multicolumn{2}{|r|}{$\lambda_{2}$} & 0.650 & 2.70 & 0.422 & 3.58 \\
\hline \multicolumn{2}{|r|}{ 尤度比 } & \multicolumn{2}{|c|}{0.172} & \multicolumn{2}{|c|}{0.236} \\
\hline \multicolumn{2}{|r|}{ サンプル数 } & \multicolumn{2}{|c|}{642} & \multicolumn{2}{|c|}{574} \\
\hline
\end{tabular}

日にはその逆になっており, 興味深い.これは, 平日 の方が，Int值の低い街路で構成された地区に存在する ような店舗の選択確率が高まり，裏通りや奥まった空 間にまで入り込むことがあること分かる.

ゾーンのInt值の分散の符号は平日，休日ともに正で ある．これは，地区ごとのInt值のばらつきが大きい猥 雑性の高いような地区に存在する店舗の方が効用が高 いことを示す．目的地までの最短経路が持つInt值の分 散は平日，休日ともに負であり，訪問する店舗までの 経路上のリンクのInt值の変化率が小さい経路をもつ店 舗を選択することを示している.

\section{b) Level-2 活動内容選択モデル}

表-6にLevel-2の活動内容選択モデルの推定結果を示す. 統計的に有意ではない変数もいくつか見られるものの， モデル全体の尤度比は高く，モデルの適合度は高い．

平日のモデルでは, 年齢を学習, 同一活動ダミーを 買物の効用関数に，休日のモデルでは，年齢を娛楽鑑 賞，同一活動ダミーを買物の効用関数に説明変数とし て導入している．同一活動ダミー（買物）の符号は平 日が正，休日が負であることから，平日には同一の買 物活動を続けて選択するほど買物の効用は高く, 休日 にはそれまでに買物をしていない方が同一の買物活動
を行う効用が高いなど，平日と休日で異なる推定結果 が得られた. 活動人数の符号が平日，休日ともに負で あることから，買物は回遊人数が少ないほど効用が高 く, 年齢の符号が負であることから, 学習, および娛 楽鑑賞は年齢が低いほど効用は高くなるなど，符号条 件についてもおおよそ論理的なモデルが推定されてい るといえよう. $\lambda_{1}$ は $0 \leq \lambda_{1} \leq 1.0$ を満たしており，仮 定した選択肢の階層構造の妥当性を示している.

\section{c) Level-1 回遊継続，帰宅選択モデル}

表-7にLevel-1の回遊継続か帰宅かの選択モデルの推定 結果を示寸，尤度比はお拉むね高く，モデルの適合度 は高い.また，t值は居住地ダミーと公共交通機関ダミ 一が低い值となっているが，その他の值はおおむね高 い值をとっている，回遊継続の効用関数には，滞在時 間，回遊時の現在時刻，居住地ダミー，公共交通機関 ダミー，居住地ダミーをそれぞれ説明変数として導入 している. 推定結果をみると, 回遊継続の効用関数で ある現在時刻, 市街地滞在時間, 居住地ダミーの推定 值符号はいずれも負になっている．現在時刻，市街地 滞在時間が負ということは，現在時刻が早く，それま での市街地滞在時間が短いほど回遊継続の効用が高く なるということであり，符号条件も論理的である．ま 
表-8＼cjkstart滞在時間モデルの推定結果

\begin{tabular}{|c|c|c|c|c|c|}
\hline \multirow{2}{*}{\multicolumn{2}{|c|}{ 説明変数 }} & \multicolumn{2}{|c|}{ 平日 } & \multicolumn{2}{|c|}{ 休日 } \\
\hline & & 推定值 & $\mathrm{t}$ 值 & 推定值 & $\mathrm{t}$ 值 \\
\hline \multirow{5}{*}{ 形状パラメータ $\beta$} & 居住地ダミー(熊本市内在住＝1) & -0.295 & -2.53 & 0.312 & 3.35 \\
\hline & 公共交通機関ダミー(公共交通=1) & -0.364 & -3.39 & -0.213 & -2.41 \\
\hline & 性別(男性＝1) & -0.212 & -1.72 & 0.0742 & 0.828 \\
\hline & 市街地滞在時間(h) & 0.202 & 6.72 & 0.227 & 5.87 \\
\hline & 現在時刻 & 0.528 & 2.35 & -0.799 & -4.42 \\
\hline \multicolumn{2}{|r|}{ 尺度パラメータ $\alpha$} & 0.253 & 8.30 & -0.0558 & -1.82 \\
\hline \multicolumn{2}{|r|}{ 最大対数尤度 } & \multicolumn{2}{|c|}{$\frac{1}{-647}$} & \multicolumn{2}{|c|}{-594} \\
\hline \multicolumn{2}{|r|}{ サンプル数 } & \multicolumn{2}{|c|}{570} & \multicolumn{2}{|c|}{545} \\
\hline
\end{tabular}

た，居住地ダミーが負ということは，熊本市外在住者 のほうが回遊継続の効用が高いことを示している。ま た，帰宅の効用関数である公共交通機関ダミーの推定 值の符号が正になっている。 これは公共交通機関を利 用して来街した人のほうが州宅の効用が高く, 遠方か らマイカーなどで来街している人ほど回遊を継続しや すい, ということであり，これも符号は論理的である. また， $\lambda_{2}$ は $0 \leq \lambda_{2} \leq 1.0$ を満たしており，あらかじめ 仮定した選択肢の階層構造は妥当である.

\section{（4）滞在時間モデルの推定結果}

本研究では, 来街者が回遊した全ての店舗での滞在 時間データを使って滞在時間モデルを推定した. 表-8 に推定結果を示す, 性別ダミーの值は低くなっている が，その他の淔は高く，統計的に有意である.

形状パラメータ $\beta に は$ 説明変数として市街地滞在時間, 現在時刻, 居住地ダミー, 公共交通機関ダミー, 性別 ダミーを導入している． 形状パラメータ $\beta$ の值が大き くなるほど早期に急激に店舗から離れる確率が高くな ることを表しており，推定值の符号が正であれば，符 号が負のものより滞在を打ち切りやすい（滞在時間が 短くなる）ことを示寸. 居住地ダミー, 公共交通機関 ダミー, 性別ダミーが負であることから, 平日には, 熊本市外在住で来街交通手段が公共交通機関ではない 女性ほど滞在時間が長くなる。 さらに, 現在時刻と市 街地滞在時間の符号が正であることから, 現在時刻が 早く, 市街地滞在時間が短いほど, 訪問先の店舗に長 く滞在することを示している. 一方，平日は現在時刻 の符号が正であるのに対し，休日は負である。これは， 現在時刻が遅くなったときに, 平日の方がより急激に 店舗から離孔る確率が高くなることを示している，市 街地滞在時間の符号は平日, 休日ともに正であるが, 休日の推定值の方が大きくなっている. これは市街地 滞在時間が長くなれば, 平日よりも休日の方が急激に 店舗から離れる確率が高くなることを示している. サ ンプルを個別に見ると, 平日は市街地滞在時間が長く
なったとしても，業務などで訪問先の店舗に滞在し続 けているサンプルが多く見られる.

\section{5. 回遊シミュレーション}

\section{(1) サンプルの拡大}

\section{a) 拡大の方法}

ここでは，回遊行動アンケート調査のサンプルを拡 大寸る方法について述べる. サンプルベースの回遊行 動データと断面交通量のデータを組み合わせる拡大方 法について最も基本的な考え方は，断面交通量を出来 るだけ再現するようにサンプルのツアー数を拡大する 方法である。ここでッアーとは，ある断面を通る回遊 行動のことを指寸. 本研究では, 商店街通行量調查, ゲートカウント調査を行った熊本市中心市街地の断面 交通量を利用してサンプル全体を一律に拡大寸る。

拡大率を $\alpha$ とすると, 拡大後の断面 $i(i=1, \cdots, n)$ の 通行量の推定值 $V_{i}$ は下記となる.

$$
V_{i}=\alpha v_{i}
$$

ここでは $v_{i}$ サンプル上の断面 $i$ の通行量である.

拡大後の断面交通量の推定值が，観測された断面交 通量 $V_{i}^{*}$ に出来るだけ一致するように拡大係数を求める 問題は，次のように表現できる.

$$
\min : S=\sum_{i}^{n}\left(V_{i}-V_{i}^{*}\right)^{2}=\sum_{i}^{n}\left(\alpha v_{i}-V_{i}^{*}\right)^{2}
$$

$S$ を最小化する $\alpha$ は, $d S / d \alpha=0$ より, 次式となる.

$$
\alpha=\sum_{i}^{n} v_{i} V_{i}^{*} / \sum_{i}^{n} v_{i}^{2}
$$

\section{b) 拡大結果}

本研究では, ゲートカウント調查地点のうち商店街 通行量調查の地点に一致する26地点の中で, 歩行者回 遊サンプルデータの作成したネットワークと一致する 21地点を用いて拡大係数を推定した.

式(15)に帰着する拡大係数の推定結果を表-9に示す.

また，図-7，図-8には商店街通行量調査の実測值とモデ ルによる推計值を示す。休日については，概ね実績值 
表-9 拡大係数と相関係数

\begin{tabular}{l|c|c}
\hline & 平日 & 休日 \\
\hline 拡大係数 & 73 & 118 \\
\hline 相関係数 & 0.90 & 0.93 \\
\hline 決定係数 & 0.81 & 0.87 \\
\hline
\end{tabular}

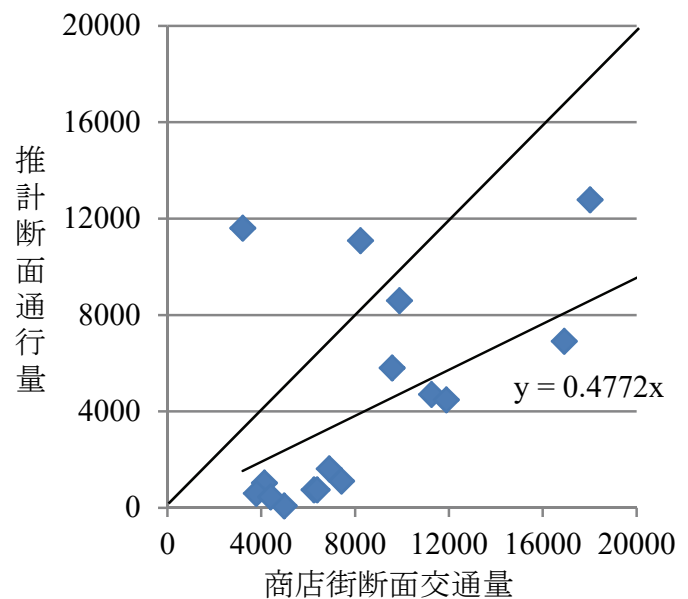

図-7 実測值と推計值の相関（平日）

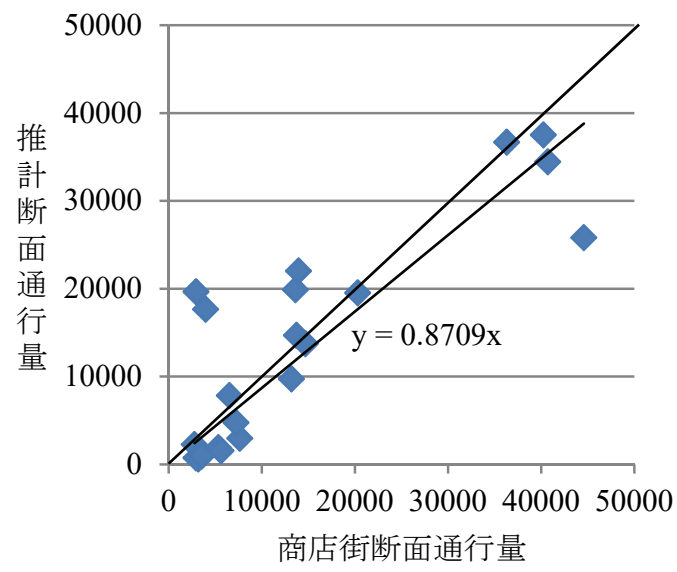

図-8 実測値と推計值の相関（休日）

を再現するような拡大率が得られたのに対して, 平日 についてはかなり過小推計されるような拡大率となっ た.これは全サンプルを一律に拡大する単一の拡大係 数を推定したためである. 精度の向上を図るためには 来街利用交通手段や歩行者回遊行動アンケートの実施 地点など，セグメントごとの拡大率を推定すると良い. その方法と結果については文献9) に譲る。信頼性にや や課題はあるものの，ここでは，上記の拡大率を用い て回遊シミュレーションを実行する.

\section{（2）現況再現性の検証}

ここでは，推定したモデルがどの程度，実績を再現 できるかを検証するため，2 章の図-3 で示した行動を再 現するシミュレーションを行い, 現況の推定值と実績 值との比較を行う.

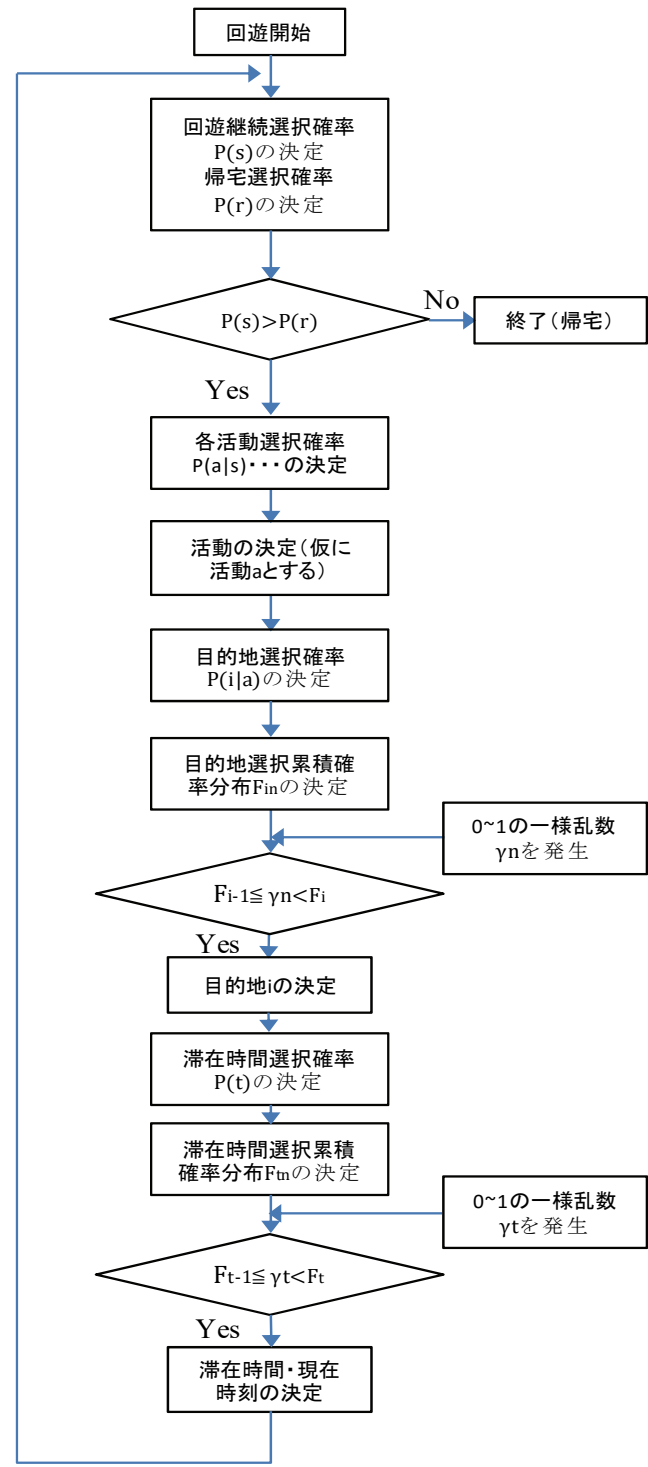

図-9 ミクロシミュレーションのフロー

\section{a) シミュレーションの方法}

モンテカルロ法によって個人の回遊行動を再現する ミクロシミュレーションのフローを図-9 に示し，各段 階の手順を示す.

手順 1 : 発ゾーン，現時刻を入力する.

手順 2：目的地選択モデルに個人 $n$ の個人属性や複合商 業ダミーといった説明変数データを代入し，全ての目 的地ごとの選択確率 $P_{i n}$ を求める. この時，どの個人も 一度は店舗を訪問すると仮定する。求めた目的地選択 確率から累積確率分布 $F_{\text {in }}$ を作成する.

手順 $3:[0,1]$ の一様乱数 $\gamma_{n}$ を発生させ， $\gamma_{n}$ の值が $F_{i-1} \leq \gamma_{n}<F_{i}$ を満たす店舗 $i$ を目的地として選択する ものとする。

手順 4 : 滞在時間モデルに個人属性や市街地滞在時間, 現在時刻等の説明変数データを代入し，累積帯在時間 分布を作成する. 手順 3 と同様に一様乱数を発生させ， 滞在確率に対応する滞在時間を決定する. 市街地滞在 


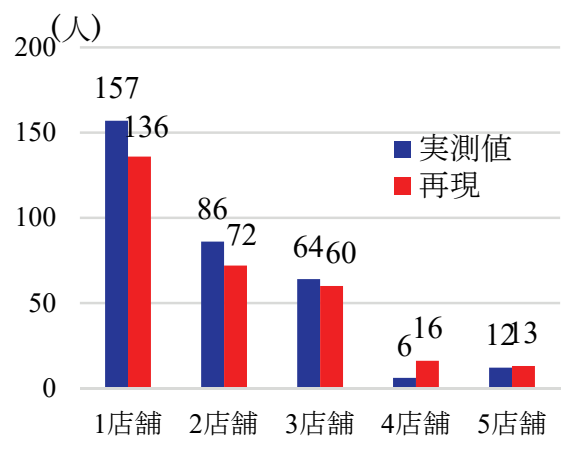

図-10 立ち寄り店舗数の再現性(平日)

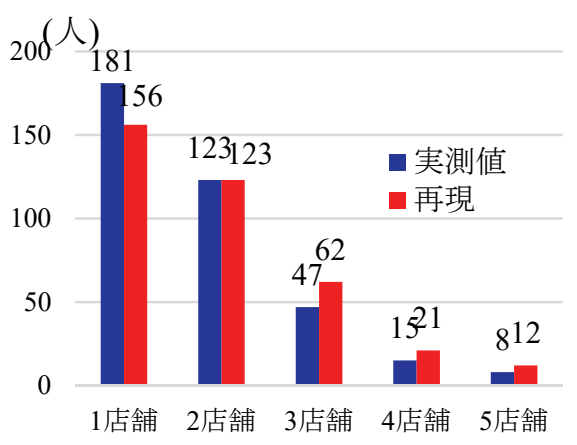

図-11 立ち寄り店舗数の再現性(休日)

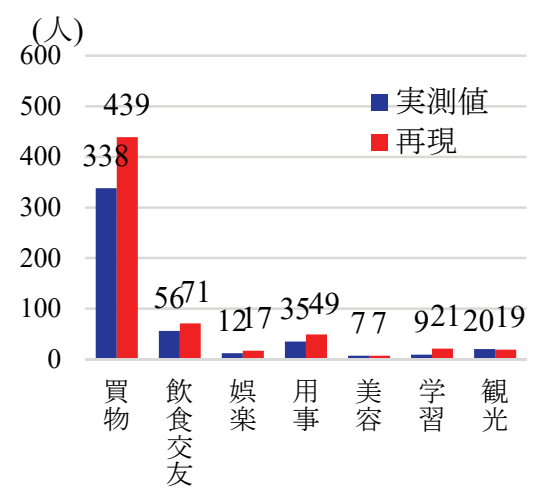

図-12 全活動別訪問店舗数の再現性(平日)

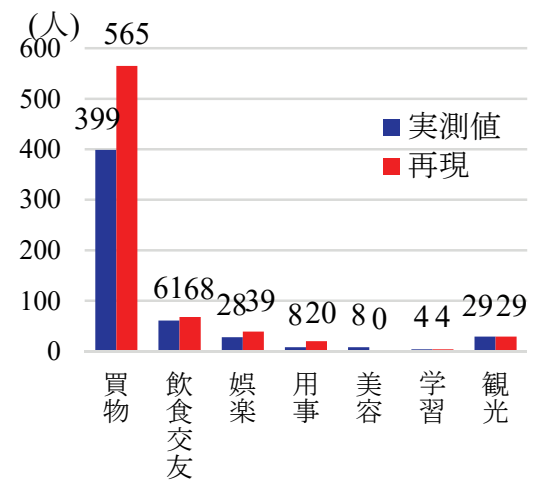

図-13 全活動別訪問店舗数の再現性(休日)

時間は発ゾーンから決定した店舗までの所要時間，現 時刻は回遊開始時刻に市街地滞在時間を加えた值とな る.

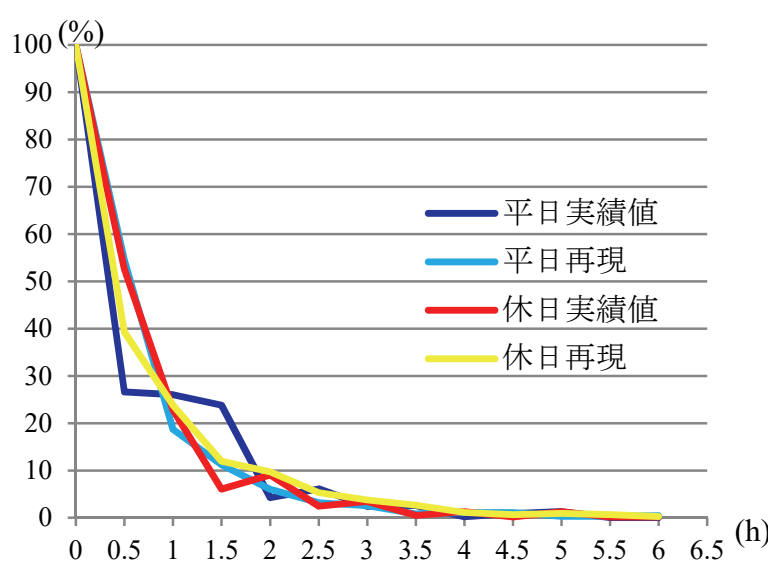

図-14 店舗滞在時間分布の再現

手順 5 : 手順 4 で求めた店舗滞在時間をそれまでの市街 地滞在時間と当該店舗到着時刻に加えることによって, 市街地滞在時間と現在時刻を算出する。また，第 1 目 的地で行った活動と同一かどうかによって同一行動ダ ミーを求める. これらを目的地選択モデルの説明変数 に代入して次の目的地の選択確率を求める. その後, 手順 3 と同様にして次の目的地を決定する.

手順 6 : 手順 3 手順 5 の操作を回遊継続する個人がい なくなるまで繰り返す．ただし， 5 店舗以上回遊したサ ンプルはごくわずかでであったため，第 5 目的地選択 が終了した時点でシミュレーションを終了する.

以上の操作を全サンプルに対して 10 回実行し，実績 值と比較する評価指標の平均值を算出した.

\section{b) 現況の再現性の検証}

まず，図-10 と図-11 に平日と休日の立ち寄り店舗数 を示す．平日，休日ともに実績を再現できていること が分かる.

図-12と図-13は回遊行動のなかで行った活動別の訪 問店舗数を示している．平日，休日ともに，買物活動 を除いた活動については，推計值は訪問店舗数の実績 值と一致している。しかし，買物活動については，両 日とも，過大に推計されている.

図-14は平日と休日の時間経過に伴う店舗滞在者率の 推移を示している．平日，休日ともに分布形状は類似 していることから，現況の店舗滞在者率を精度良く再 現できていると言えよう.

これらの結果から，サンプルベースでの現況再現性 を見る限り，目的地選択モデルと滞在時間モデルを組 み合わせた回遊行動モデルは熊本中心市街地での回遊 行動を高い精度で表現できていると言える.

図-15 と図-16 に平日と休日のゾーンごとの入れ込み 人数の実績值と再現值の比較を示す．その際，サンプ ルベースの再現值を拡大係数によって拡大した值を各 地区の入れ込み人数とした. 平日については, ゾーン 1 


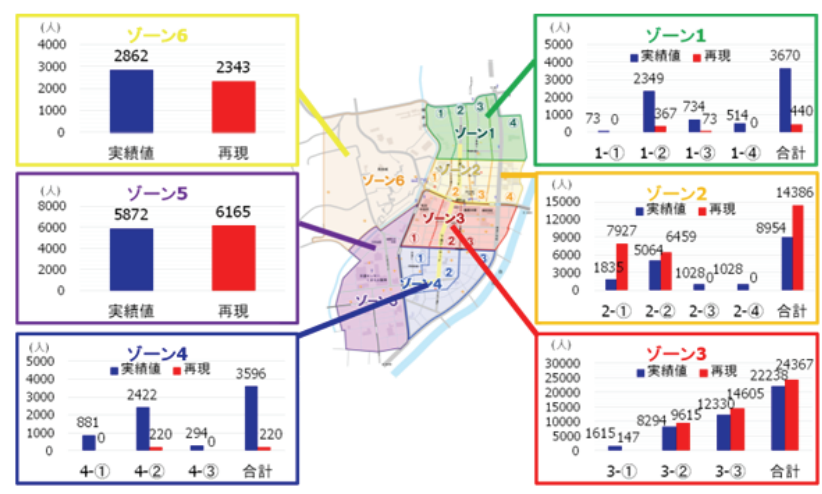

図-15 ゾーン別入れ込み人数の現況再現（平日）

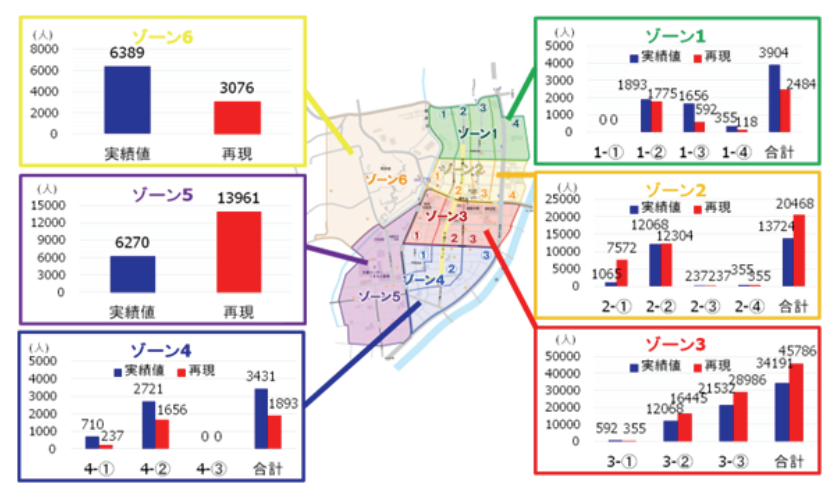

図-16 ゾーン別入れ込み人数の現況再現（休日）

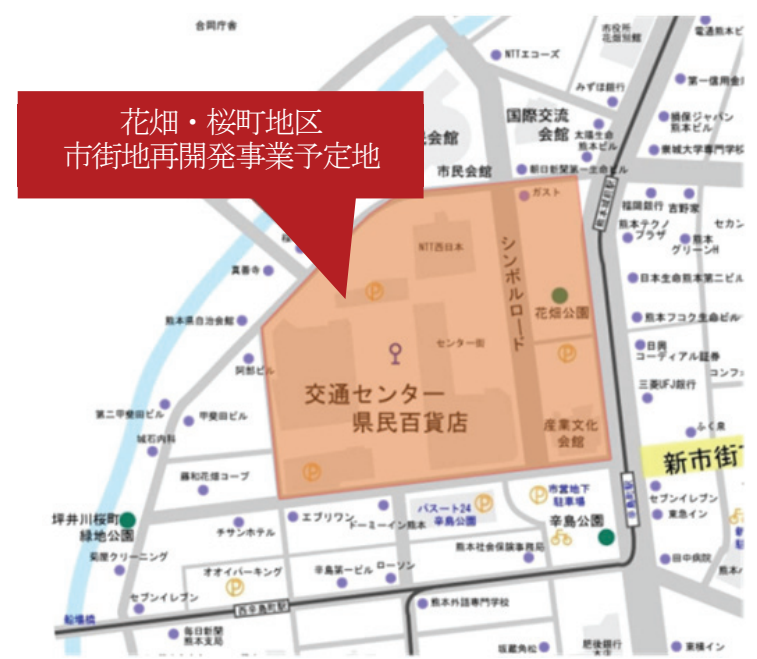

図-17 花畑・桜町地区市街地再開発事業予定地

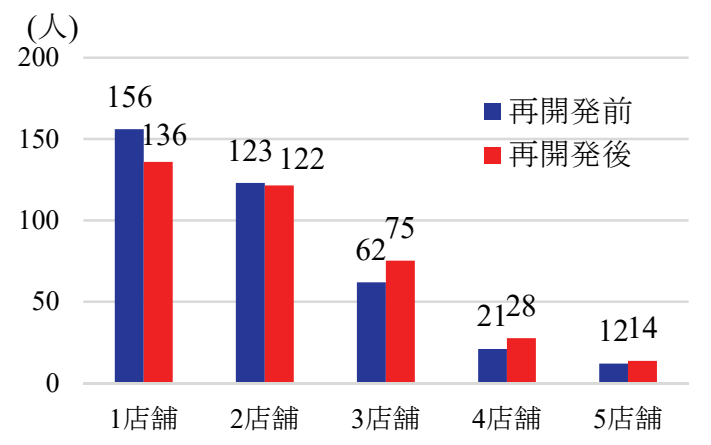

図-18 立ち寄り店舗数の比較

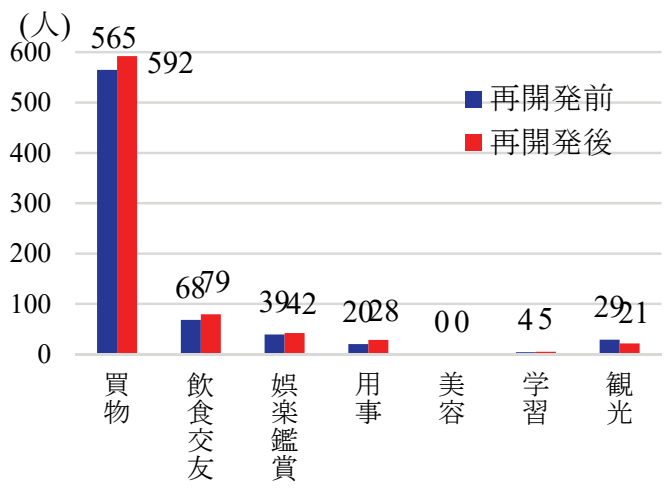

図-19 全活動別訪問店舗数の比較

表-10 小ゾーンごとの入れ込み人数の 実績値と再現值の相関

\begin{tabular}{c|c|c}
\hline \multirow{2}{*}{ 相関係数 } & 平日 & 休日 \\
\cline { 2 - 3 } & 0.95 & 0.97 \\
\hline$R^{2}$ & 0.91 & 0.95 \\
補正済 $R^{2}$ & 0.89 & 0.93
\end{tabular}

とゾーン4で実績值より過小に推計されているが，その 他のゾーンでは現況の入れ込み人数をうまく再現して いる. 休日については，ゾーン2とゾーン5では過大に, ゾーン1とゾーン4では過小に入れ込み人数が推計され ているが，その他のゾーンでは実績值に近い推計值が 得られている.

表-10は小ゾーン（15ゾーン）ごとに入れ込み人数の 実績值と再現值を比較した結果を示している．両者と もに相関係数は高く，小ゾーンごとに見ても，入れ込 み人数の推計值の信頼性は高い.

\section{(3) 花畑・桜町地区再開発のシミュレーション分析}

次に, 現在熊本市が計画している花畑・桜町地区の 再開発事業（桜町地区第一種市街地再開発事業）が完 了した場合に回遊行動にどのような変化が見られるの かを回遊行動モデルを用いて予測する．再開発前後の ゾーン別入れ込み人数の変化を(2)でシミュレートした 結果を現況として比較する. 設定としては, 図-17 に示 寸場所に商業施設やバスターミナルを備えた複合商業 施設が建設（複合商業施設ダミー=1）されるために店 舗面積が変化すると同時に，周辺の街路がプロムナー ドとして拡幅整備されるため, 道路ネットワークが変 化することによって，主として周辺のInt 值も変化する. 今回は休日サンプルを用いてシミュレーションを行い, 個人属性などの来街者の設定は調査時のままとした.

図-18 は再開発前後での立ち寄り店舗数の比較と再開 発前後での平均立ち寄り店舗数の変化を示している. 再開発前は 1 店舗，もしくは 2 店舗目まで訪問してい た人が減少し， 3 店舗，もしくは 4 店舗， 5 店舗目まで 
訪問している人が増加している. 平均立ち寄り店舗数 を見ると，再開発前は 1.95 回であったが，再開発後は 2.08 回であり, 再開発事業により全体的に立ち寄り店 舗数が増加することが分かる。これは，再開発前の訪 問先に加えて, 再開発後は複合商業施設を訪問する回 遊に行動が拡大したためである.

図-19 は再開発前後での活動別の訪問店舗数の変化を 示している. グラフ形状はほぼ一致しており, 活動に ついて再開発前後であまり変化は見られない.

図-20 は再開発前後での店舗滞在時間と回遊者全体の 市街地帯在時間の変化を示している. 店舗帯在時間分 布は再開発前後で分布形状はほぼ一致しており，店舗 滞在時間には再開発前後であまり変化は見られない.

一方，回遊者全体の平均市街地滞在時間は再開発前は

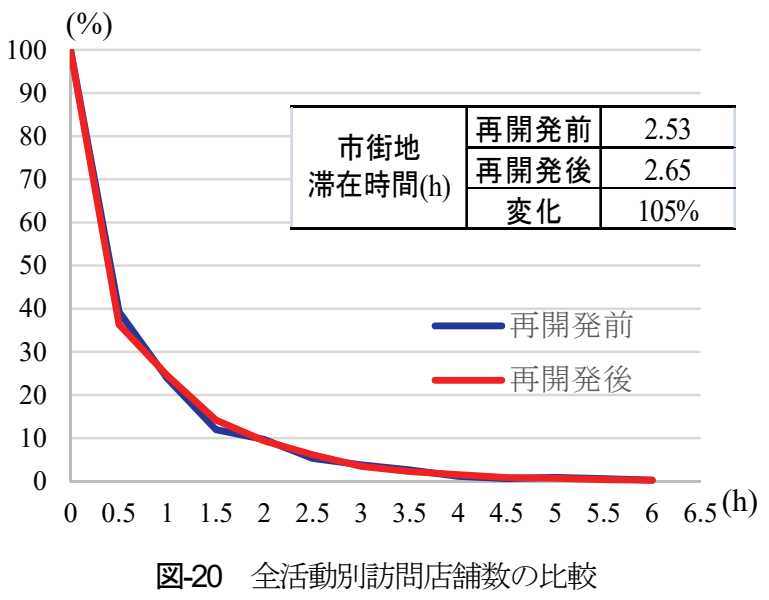

約 2.53 時間であったが，再開発後は約 2.65 時間であり， で約 7 分間増加している.

図-21 は再開発前後でのゾーン別入れ込み者数の比較 を示している．再開発予定地を含むゾーン 5 の入れ込 み人数が増加していることが分かる.ゾーン 1 の入れ 込み人数がやや減少しているが，その他のゾーンの入 れ込み人数はあまり減少していないので，全体的な回 遊回数が増えたうえで，ゾーン 5 に人が流入し，回遊 行動が活発化していることが分かる.

これらのことから，花畑・桜町地区再開発が完了し たときの回遊行動の変化を構築したモデルによって表 現することができた.

\section{6. おわりに}

以下に本研究で得られた主な成果と今後の課題を併 記する。

1) SS理論によるInt值を導入した訪問店舗選択モデルを 推定し, 街路構成のもつ魅力度が回遊行動に与える影 響を考慮したモデルを構築できた.

2) 目的地選択モデルと滞在時間モデルを組み合わせ， 時間経過を考慮した歩行者の回遊行動を精度良く表現 することができた.

3）既存研究の課題であった平日，休日の両方のサンプ ルを用いた回遊行動モデルを構築し，熊本市中心市街 地における平日と休日の回遊行動の比較をすることが

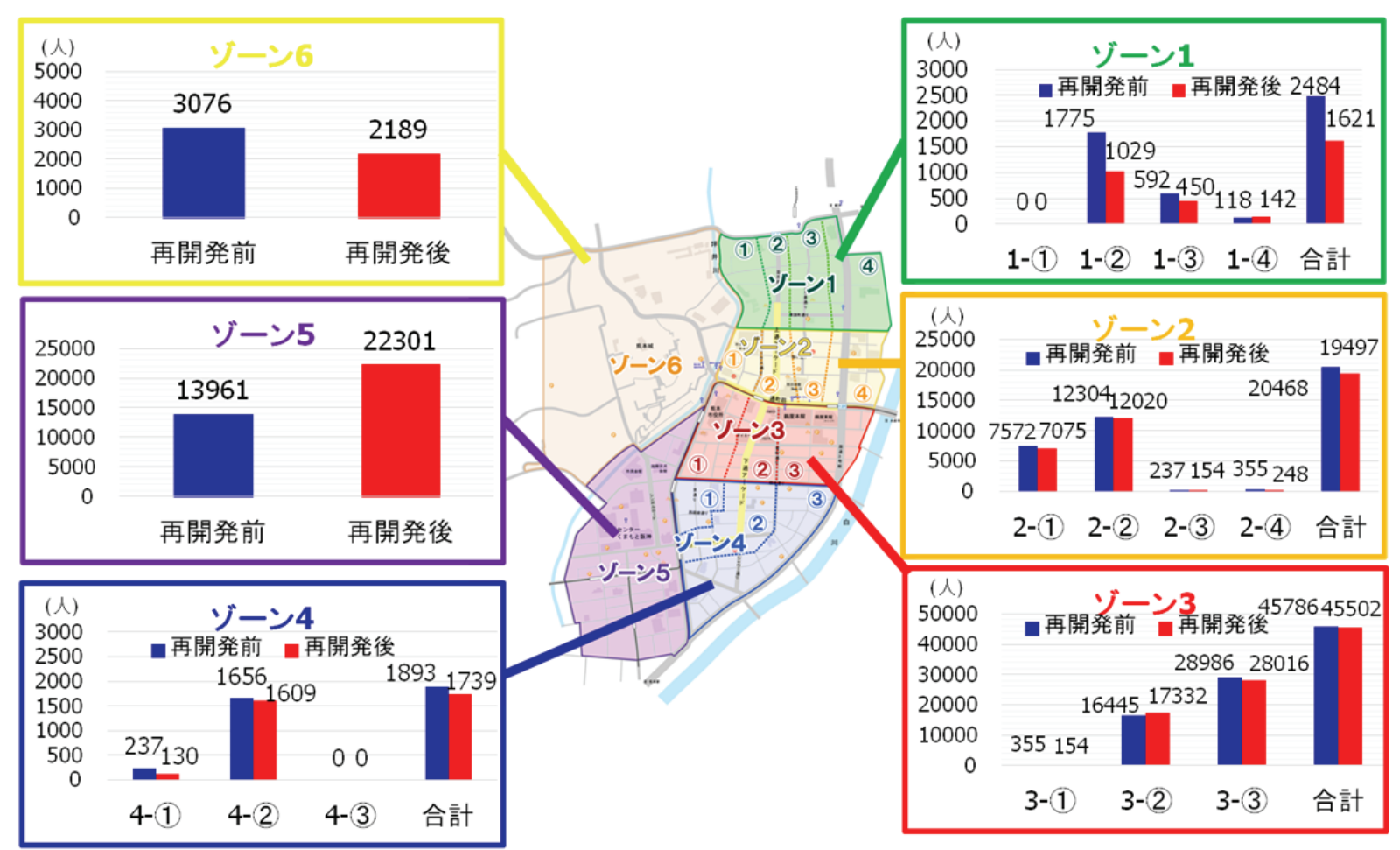

図-21 再開発前後のゾーン別入れ込み人数の比較（休日） 
できた。

4) 花畑・桜町地区再開発によって立ちより店舗数，お よびゾーンへの入れ込み人数が増加することを示唆し た. また, 中心市街地での市街地滞在時間の増加が見 込まれることが分かった。

5) 2013年11月から12月の土・日曜日の6日間, 本研究の 対象地域と同一の地域で実施されたスマートフォンア プリの「スマくま」を用いたまちなか回遊調査 ${ }^{10)} な と ゙ ，$ 他の調查手法から得られた回遊行動データとの補完・ 融合・代替の可能性などについて，検討を行うことが 求められる.

\section{参考文献}

1) 加藤憲一: 業種別商業集積に基づく商業地域の回遊行 動モデル，都市計画論文集，No.44-2，pp.8-13， 2009.

2) 石川宏之 : 地方都市中心市街地における来街者の回遊 行動と小規模賃貸店舗の展開に関する研究—青森県八 戸市中心市街地を事例として一, 都市計画論文集, No.44-3, pp.193-198, 2009.

3) 福山祥代, 羽藤英二 : 行動データに基づく歩行者行動 特性を考慮した街路ネットワーク分析一渋谷歩行圈を 対象として一，都市計画論文集，No.47-1，pp.62-67， 2012.
4) 川辺充載, 川島和彦：路面電車利用者の中心商業地区 における回遊行動に関する研究一広島市における路面 電車利用者の行動特性と中心商業地区の空間格子に着 目して一，都市計画論文集，No.47-2，pp.168-173， 2012.

5) 氏原岳人, 阿部宏史, 入江恭平, 有方 聡 : 二局の特 性の異なる商業エリアを有する中心地外地の回遊行動 の実態分析，都市計画論文集，No.49-3，pp.801-806， 2014.

6) 熊本商工会議所, 商店街通行量調查： http://www.kmtcci.or.jp/investigation/shopstreet.php

7) Hillier, B. and Hanson, J.: The Social Logic of Space, Cambridge University Press, 1984.

8) Hillier, B. and Iida, S.: Network and Psychological Effects in Urban Movement, Spatial Information Theory, LNCS3693, pp.475-490, 2005.

9) 溝上章志, 高松誠治, 吉住弥華, 星野祐司 : 中心市街 地における空間構成と歩行者回遊行動の分析フレーム ワーク，土木学会論文集 D3 (土木計画学), Vol.68, No.5, pp.I_363-I_374, 2012.

10) 井村祥太郎, 佐藤貴大, 円山玩也 : スマホアプリ型回 遊調査のデータ特性と SVM による移動滞在判別の基 礎分析, 土木計画研究 ・講演集, Vol.50, PaperNo.225, 2014.11.

(2015. 2. 27 受付)

\section{AN ANALYTICAL METHOD OF INDIVIDUAL EXCURSION BEHAVIOR IN THE CENTRAL CITY AREA}

\section{Masahiro ARAKI, Shoshi MIZOKAMI and Takuya MARUYAMA}

In recent years, Kumamoto has taken various measures to improve charm and vitality of central city area. Among them it is believed that promoting the excursion of the pedestrian is one of the effective measures to make central city active. To that end, we need to analyze the actual situation of the excursion of the pedestrian in details, and it is necessary to clarify the factors and mechanisms that have an influence on the excursion. This study has two purposes, the first one is to build the model that introduces the index of spatial configuration into explanatory variables which are able to contribute the policy proposal for spatial charm's improvement. The second one is to analyze the effect of the excursion behavior on a redevelopment project in Sakuramachi area by performing policy simulation that utilized the model. 